\title{
Peningkatan Produksi Tanaman Bawang Daun (Allium Fistusolum) Melalui Aplikasi Pupuk Organik Cair Rumput Laut (Sargassum sp.) di Kota Wisata Batu
}

\author{
KADEK LENI ${ }^{*}$, MOCH. FADIL, DAN ACHMAD NIZAR \\ Program Studi Penyuluhan Pertanian Berkelanjutan, Politeknik Pembangunan \\ Pertanian Malang \\ J1. Dr. Cipto 144A, Bedali Lawang Malang, Jawa Timur \\ ${ }^{*}$ E-mail: kadekleni@gmail.com
}

\begin{abstract}
The Effect of Providing Seaweed Liquid Organic Fertilizer (Sargassum sp) on The Growth and Production of Leaf Onion (Allium Fistusolum). Market demand for leaf onion has increased from year to year but the growth and production of leaf onion has not increased because the farmers always fertilize using chemical fertilizers. This study aims to determine the effect of seaweed liquid organic fertilizer on the growth and production of leaf onions. The study was conducted on a land area of $30 \mathrm{~m} 2$ in Tulungrejo Village, Bumiaji, Batu - Malang. The experiment used CRD (Completely Randomized Design) with 5 treatments and 5 replications. The treatment carried out were without giving of seaweed liquid organic fertilizer on the leaves onion plant (P0), giving seaweed liquid organic fertilizer to the leaves onion plant with a concentration of $5 \mathrm{ml} /$ liter (P1), $10 \mathrm{ml} /$ liter (P2), $15 \mathrm{ml}$ / liter (P3), and $20 \mathrm{ml} /$ liter (P4). The parameters observed were plant height growth, growth in number of leaves and weight of harvesting leaf onion. Observation data were analyzed using analysis of variance level 5\% and Duncan's advanced test at 5\% level. The results showed that the application of seaweed liquid organic fertilizer had a significant effect on the growth of leaf onion plants and the production of onion leaf. On the growth of the number of leaves, the application of seaweed liquid organic fertilizer did not have a significantly effect on the leaf onion plants in the age of 63 days after planting.
\end{abstract}

Keywords: Seaweed Liquid Organic Fertilizer, Leaf Onion, Seaweed

\section{PENDAHULUAN}

Komoditas sayuran menjadi komoditas terfavorit masyarakat di Jawa Timur karena komoditas sayuran memiliki vitamin dan mineral yang melimpah sehingga baik untuk kesehatan. Salah satu komoditas sayuran yang patut diperhatikan adalah bawang daun.

Bawang daun merupakan salah satu jenis komoditas sayuran yang sangat berpotensi untuk dikembangkan secara 
KADEK LENI. et al. Peningkatan Produksi Tanaman Bawang Daun (Allium Fistusolum)...

intensif dan komersil khususnya di Bumiaji, Batu. Hal ini disebabkan oleh kondisi dan keadaan lahan dan cuaca di Bumiaji Batu yang sesuai untuk

berbudidaya tanaman dilihat dari syarat tumbuh tanaman bawang daun. Selain karena memenuhi syarat tumbuh tanaman bawang daun juga disebabkan oleh permintaan pasar yang tiap tahun semakin meningkat namun faktanya hasil produksi tanaman bawang daun di Desa Tulungrejo tidak terjadi peningkatan tiap tahun. Hasil produksi tanaman bawang daun tiap musim tanam selalu berkisar 10 ton / ha. Sedangkan produksi optimum tanaman bawang daun per musim tanam adalah 20 ton/ha (Rukmana R., 1995)

Menurut Rukmana R. (1995) menyatakan bahwa tanaman bawang daun membutuhkan pupuk yang mengandung unsur $\mathrm{N}$ yang banyak agar dapat memaksimalkan pertumbuhannya. Namun petani setempat terbiasa melakukan pemupukan menggunakan pupuk kimia yang menyebabkan pengerasan lahan, mengurangi unsur hara mikro, mencemari air tanah, berkembangnya hama dan penyakit tertentu sehingga pada akhirnya menurunkan hasil produksi tanaman bawang daun. Pemberian pupuk organik cair dianggap menjadi solusi dalam meningkatkan ketersediaan unsur hara yang aman, terkendali dan tidak menimbulkan masalah baru. Selain itu poc cenderung mudah dibuat dan bahanbahannya mudah diperoleh. Salah satu bahan yang mudah diperoleh adalah rumput laut (Nugroho Panji, 2018).

Berdasarkan permasalahan tersebut maka perlu dilakukan penelitian tentang pengaruh pemberian pupuk organik cair rumput laut terhadap pertumbuhan dan produksi tanaman bawang daun.

\section{BAHAN DAN METODE}

Penelitian ini dilakukan pada lahan milik Bapak Gembos luas $30 \mathrm{~m}^{2}$ dengan ukuran bedengan $150 \mathrm{~cm}$ x $70 \mathrm{~cm}$ x $25 \mathrm{~cm}$ di Desa Tulungrejo Kecamatan Bumiaji Batu. Pembuatan pupuk organik cair dilakukan dengan cara fermentasi rumput laut varietas Sargassum sp. pada ember bekas di Kantor Kebun Kampus Politeknik Pembangunan Pertanian Malang.Penelitian berlangsung dari bulan Januari hingga bulan April 2019.

Penelitian ini menggunakan RAK (Rancangan Acak Lengkap) dengan 5 perlakuan. Perlakukan yang dilakukan adalah tanpa pemberian pupuk organik cair rumput laut (P0), pemberian pupuk organik cair rumput laut dengan konsentrasi $5 \mathrm{ml} / \mathrm{liter}$ (P1), 10 ml/liter (P2), 15 ml/liter (P3), dan 20 $\mathrm{ml} /$ liter (P4). Konsentrasi ditentukan 
berdasarkan rekomendasi konsentrasi pupuk organik cair untuk tanaman sayuran 10ml/1 (Nugroho Panji, 2018). Tiap perlakuan dilakukan pengulangan sebanyak 5 kali. Parameter yang diamati yaitu pertumbuhan tinggi tanaman $(\mathrm{cm})$ per tanaman , pertumbuhan jumlah daun (helai) per tanaman dan bobot panen tanaman bawang daun (gram) per tanaman. Parameter pertumbuhan tinggi tanaman dan jumlah daun dilakukan setiap 10 hari sekali sebanyak 6 kali selama masa tanam. Parameter bobot panen dilakukan sekali hanya pada saat panen.

Bahan yang diperlukan adalah bibit bawang daun varietas layur, pupuk organik cair rumput laut, ember sebagai wadah campuran pupuk organik, penggaris dan timbangan elektrik sebagai alat ukur pengamatan. Bahan untuk membuat pupuk organik cair rumput laut Sargassum sp. yaitu rumput laut jenis Sargassum $s p .1 \mathrm{~kg}$, EM4 200ml, air 10 liter, serta gula moleses 200ml. Permbuatan pupuk organik cair dan penanaman tanaman bawang daun dilakukan pada tanggal 15 Februari 2019. Penyiraman tidak perlu dilakukan dua kali tiap hari karena memperhatikan tingkat kelembapan yang dimiliki tanah sudah mencapai 85\% (Cahyono Bambang, 2005). Pemupukan dilakukan ketika tanaman berumur 5 HST,
10 HST, 15 HST, 20 HST, 25 HST, 30 HST, 35 HST, 40 HST, 45 HST, 50 HST, dan 55 HST . Pemupukan dilakukan dengan cara disiram. Pengamatan mulai dilakukan ketika tanaman sudah berumur 10 HST. Kegiatan panen dilakukan saat tanaman sudah berumur lebih dari 60 HST.

Data yang diperoleh kemudian dianalisis menggunakan Analisis of Variant (Anova) bertaraf 5\% melalui aplikasi SPSS (Statistical Product and Service Solutions) IBM 20 dan apabila terdapat beda nyata maka dilanjutkan dengan uji Duncan's pada taraf 5\% melalui aplikasi SPSS (Statistical Product and Service Solutions) IBM 20.

\section{HASIL DAN PEMBAHASAN}

Berdasarkan analisis data pengamatan yang telah dilakukan maka diperoleh hasil bahwa pemberian pupuk organik cair rumput laut dari pengamatan umur 10 HST hingga pengamatan umur 63 HST memiliki pengaruh nyata terhadap pertumbuhan tinggi tanaman dan bobot panen tanaman bawang daun. Namun pada parameter pertumbuhan jumlah daun, pengaruh yang signifikan hanya terjadi pada pengamatan umur 10 HST hingga umur 50 HST saja. Hasil uji anova umur 63 HST melalui aplikasi SPSS pada parameter jumlah 
KADEK LENI. et al. Peningkatan Produksi Tanaman Bawang Daun (Allium Fistusolum)...

daun menunjukan terjadi beda nyata ditandai dengan nilai sig. $0.00<0.05$. Kemudian dilanjutkan dengan uji lanjut Duncan 5\% dengan memperoleh nilai subset sebesar 0.650 untuk semua perlakuan. Hal ini menunjukan bahwa pemberian pupuk organik cair tidak memberikan pengaruh nyata untuk pertumbuhan jumlah daun. Pengamatan pertumbuhan tinggi tanaman dan jumlah daun umur 10 HST dapat dilihat pada Tabel 1.

Tabel 1. Pengaruh pemberian pupuk organik cair rumput laut Sargassum sp. terhadap pertumbuhan tinggi tanaman dan pertumbuhan jumlah daun tanaman bawang daun pada umur 10 HST

\begin{tabular}{llllll}
\hline Parameter & \multicolumn{3}{l}{ Perlakuan } & & \\
\cline { 2 - 6 } & P0 & P1 & P2 & P3 & P4 \\
\hline Tinggi tanaman $(\mathrm{cm})$ & $3.25 \mathrm{a}$ & $38.22 \mathrm{~b}$ & $38.67 \mathrm{~b}$ & $39.22 \mathrm{~b}$ & $38.64 \mathrm{~b}$ \\
Jumlah daun (helai) & 3a & $3.56 \mathrm{~b}$ & $3.78 \mathrm{bc}$ & $4.16 \mathrm{c}$ & $3.89 \mathrm{c}$ \\
\hline Keterangan : angka - angka yang diikuti huruf yang berbeda & pada baris yang sama berbeda nyata pada uji \\
Duncan's taraf 5\%
\end{tabular}

Pada pengamatan parameter tinggi tanaman dan jumlah daun tanaman tanaman dan jumlah daun umur $10 \mathrm{HST}$, bawang daun perlakuan P0 sebesar 35,2 rata- rata tertinggi tinggi tanaman dan jumlah $\mathrm{cm}$ dan 3 helai (Tabel 1).

daun diperoleh tanaman dengan Pengamatan pertumbuhan tinggi perlakuan P3 sebesar 39,22 $\mathrm{cm}$ dan 4,16 tanaman dan jumlah daun umur 20 HST helai yang berbeda dengan rata-rata tinggi dapat dilihat pada Tabel 2.

Tabel 2. Pengaruh pemberian pupuk organik cair rumput laut Sargassum sp. terhadap pertumbuhan tinggi tanaman dan pertumbuhan jumlah daun tanaman bawang daun pada umur 20 HST

\begin{tabular}{|c|c|c|c|c|c|}
\hline \multirow[t]{2}{*}{ Parameter } & \multicolumn{5}{|c|}{ Perlakuan } \\
\hline & P0 & P1 & $\mathrm{P} 2$ & P3 & $\mathrm{P} 4$ \\
\hline Tinggi tanaman $(\mathrm{cm})$ & $36.49 a$ & $41.87 b$ & $42 b$ & $42.22 b$ & $41.98 b$ \\
\hline Jumlah daun (helai) & $3.64 \mathrm{a}$ & $5.22 b$ & $5.4 \mathrm{~b}$ & $5.69 b$ & $5.3 b$ \\
\hline
\end{tabular}

Keterangan : angka - angka yang diikuti huruf yang berbeda pada baris yang sama berbeda nyata pada uji Duncan's taraf 5\%

Pada pengamatan parameter tinggi daun diperoleh tanaman dengan tanaman dan jumlah daun umur $20 \mathrm{HST}$, perlakuan P3 sebesar 42,22 $\mathrm{cm}$ dan 5,69 rata- rata tertinggi tinggi tanaman dan jumlah helai yang berbeda dengan rata-rata tinggi 
tanaman dan jumlah daun tanaman Pengamatan pertumbuhan tinggi bawang daun perlakuan P0 sebesar 36,49 tanaman dan jumlah daun umur 30 HST cm dan 3,64 helai (Tabel 2). dapat dilihat pada Tabel 3.

Tabel 3. Pengaruh pemberian pupuk organik cair rumput laut Sargassum sp. terhadap pertumbuhan tinggi tanaman dan pertumbuhan jumlah daun tanaman bawang daun pada umur 30 HST

\begin{tabular}{llllll}
\hline Parameter & Perlakuan & \multicolumn{3}{l}{} \\
\cline { 2 - 6 } & P0 & P1 & P2 & P3 & P4 \\
\hline Tinggi tanaman (cm) & $40.07 \mathrm{a}$ & $44.47 \mathrm{~b}$ & $44.96 \mathrm{~b}$ & $45.87 \mathrm{~b}$ & $44.89 \mathrm{~b}$ \\
Jumlah daun (helai) & $4.87 \mathrm{a}$ & $5.96 \mathrm{~b}$ & $6.11 \mathrm{~b}$ & $6.4 \mathrm{~b}$ & $6.02 \mathrm{~b}$ \\
\hline
\end{tabular}

Keterangan : angka - angka yang diikuti huruf yang berbeda pada baris yang sama berbeda nyata pada uji Duncan's taraf 5\%

Pada pengamatan parameter tinggi tanaman dan jumlah daun tanaman tanaman dan jumlah daun umur $30 \mathrm{HST}$, bawang daun perlakuan P0 sebesar 40,07 rata- rata tertinggi tinggi tanaman dan jumlah cm dan 4,87 helai (Tabel 3).

daun diperoleh tanaman dengan Pengamatan pertumbuhan tinggi perlakuan P3 sebesar 45,87 $\mathrm{cm}$ dan 6,4 tanaman dan jumlah daun umur 40 HST helai yang berbeda dengan rata-rata tinggi dapat dilihat pada Tabel 4.

Tabel 4. Pengaruh pemberian pupuk organik cair rumput laut Sargassum $s p$. terhadap pertumbuhan tinggi tanaman dan pertumbuhan jumlah daun tanaman bawang daun pada umur 40 HST

\begin{tabular}{|c|c|c|c|c|c|}
\hline \multirow[t]{2}{*}{ Parameter } & \multicolumn{5}{|c|}{ Perlakuan } \\
\hline & $\mathrm{P} 0$ & $\mathrm{P} 1$ & $\mathrm{P} 2$ & P3 & $\mathrm{P} 4$ \\
\hline Tinggi tanaman $(\mathrm{cm})$ & $43.22 \mathrm{a}$ & $48.22 b$ & $48.42 b$ & $50.73 b$ & $48.33 b$ \\
\hline Jumlah daun (helai) & $5.69 a$ & $7.49 b$ & $7.69 b c$ & $8.2 \mathrm{c}$ & $7.64 \mathrm{bc}$ \\
\hline
\end{tabular}

Keterangan : angka - angka yang diikuti huruf yang berbeda pada baris yang sama berbeda nyata pada uji Duncan's taraf $5 \%$

Pada pengamatan parameter tinggi tanaman dan jumlah daun tanaman tanaman dan jumlah daun umur 40 HST, bawang daun perlakuan P0 sebesar 43,22 rata- rata tertinggi tinggi tanaman dan jumlah cm dan 5,69 helai (Tabel 3). daun diperoleh tanaman dengan Pengamatan pertumbuhan tinggi perlakuan P3 sebesar 50,73 $\mathrm{cm}$ dan 8,2 tanaman dan jumlah daun umur 50 HST helai yang berbeda dengan rata-rata tinggi dapat dilihat pada Tabel 5. 
KADEK LENI. et al. Peningkatan Produksi Tanaman Bawang Daun (Allium Fistusolum)...

Tabel 5. Pengaruh pemberian pupuk organik cair rumput laut Sargassum sp. terhadap pertumbuhan tinggi tanaman dan pertumbuhan jumlah daun tanaman bawang daun pada umur 50 HST

\begin{tabular}{|c|c|c|c|c|c|}
\hline \multirow[t]{2}{*}{ Parameter } & \multicolumn{5}{|c|}{ Perlakuan } \\
\hline & $\mathrm{P} 0$ & P1 & P2 & P3 & P4 \\
\hline Tinggi tanaman $(\mathrm{cm})$ & $43.91 \mathrm{a}$ & $51.29 b$ & $51.8 b$ & $55.2 \mathrm{c}$ & $51.71 b$ \\
\hline Jumlah daun (helai) & $7.69 \mathrm{a}$ & $9.71 \mathrm{~b}$ & $9.89 b$ & $10.16 b$ & $9.93 b$ \\
\hline
\end{tabular}

Pada pengamatan parameter tinggi yang diberikan pupuk organik cair rumput tanaman dan jumlah daun umur 50 HST, laut memiliki beda nyata dengan tanaman rata- rata tertinggi tinggi tanaman dan jumlah yang tidak diberikan pupuk organik cair. Hal daun diperoleh tanaman dengan ini diduga karena rumput laut memiliki perlakuan P3 sebesar 55,2 cm dan 10.16 kandungan zat pemacu tumbuh (ZPT) helai yang berbeda dengan rata-rata tinggi yang lengkap seperti auksin, sitokinin, dan tanaman dan jumlah daun tanaman bawang giberelin yang mendorong peningkatan daun perlakuan P0 sebesar $43.91 \mathrm{~cm}$ dan 7.69 pertumbuhan tanaman (Basmal J., 2009). helai (Tabel 3).

Pengamatan pertumbuhan tinggi

Berdasarkan tabel nomor 1 hingga tanaman dan jumlah daun umur 63 HST tabel nomor 5 diketahui bahwa tanaman dapat dilihat pada Tabel 6.

Tabel 6. Pengaruh pemberian pupuk organik cair rumput laut Sargassum sp. terhadap pertumbuhan tinggi tanaman dan pertumbuhan jumlah daun dan bobot panen tanaman bawang daun pada umur 63 HST

\begin{tabular}{llllll}
\hline Parameter & Perlakuan & & & \\
\cline { 2 - 6 } & P0 & P1 & P2 & P3 & P4 \\
\hline Tinggi tanaman $(\mathrm{cm})$ & $51.4 \mathrm{a}$ & $54.67 \mathrm{~b}$ & $54.51 \mathrm{~b}$ & $57.04 \mathrm{~b}$ & $54.67 \mathrm{~b}$ \\
Jumlah daun (helai) & $12.42 \mathrm{a}$ & $12.48 \mathrm{a}$ & $12.56 \mathrm{a}$ & $12.73 \mathrm{a}$ & $12.53 \mathrm{a}$ \\
Boboy Panen (gram) & $92.64 \mathrm{a}$ & $110.13 \mathrm{ab}$ & $110.42 \mathrm{ab}$ & $119.62 \mathrm{~b}$ & $110 \mathrm{ab}$ \\
\hline
\end{tabular}

Keterangan : angka - angka yang diikuti huruf yang berbeda pada baris yang sama berbeda nyata pada uji Duncan's taraf 5\%

Pada pengamatan parameter tinggi dengan perlakuan P3 sebesar 57,04 cm, tanaman dan jumlah daun umur 63 HST, 12,73 helai dan 119,62 gram yang berbeda rata- rata tertinggi tinggi tanaman, jumlah dengan rata- rata tinggi tanaman, jumlah daun dan bobot panen diperoleh tanaman daun dan bobot panen tanaman bawang daun 
perlakuan P0 sebesar 51,4 cm, 12,42 helai terhenti (Sapto W., 2015). dan 92,64 gram (Tabel 6).

Berdasarkan tabel nomor 6 diketahui bahwa pada parameter pertumbuhan tinggi tanaman dan bobot daun, tanaman yang diberikan pupuk organik cair rumput laut memiliki beda nyata dengan tanaman yang tidak diberikan pupuk organik cair. Hal ini diduga karena rumput laut memiliki kandungan ZPT yang tinggi bahkan melebihi kandungan ZPT dalam pupuk organik cair yang beredar dipasaran yang baik untuk peningkatan pertumbuhan dan hasil produksi tanaman (Berlyanto Bakti, 2014). Selain itu perbedaan konsentrasi pupuk organik cair rumput laut tidak memberikan pengaruh yang besar hal ini disebabkan karena tanaman dengan perlakuan yang diberikan pupuk organik cair sama-sama memperoleh kandungan ZPT yang terkandung dalam pupuk organik cair rumput laut.

Namun pada parameter jumlah daun, tanaman yang diberikan pupuk organik cair rumput laut tidak berbeda nyata dengan tanaman yang tidak diberikan pupuk organik cair rumput laut. Hal ini diduga pada tanaman bawang daun saat itu sudah memasuki fase generatif dimana bakal bunga dari tanaman mulai berkembang sehingga pertumbuhan daun melambat bahkan

\section{SIMPULAN}

Pemberian pupuk organik cair rumput laut Sargassum sp. memberikan pengaruh yang nyata didukung oleh hasil uji anova yang memiliki nilai sig. kurang dari 0,05 dan setelah dilakukan uji lanjut Duncan terjadi perbedaan nilai subset untuk parameter pertumbuhan tinggi tanaman dan bobot panen pada pengamatan umur 10 HST, 20 HST, 30 HST, 40 HST, 50 HST, dan 63 HST. Pada parameter pertumbuhan jumlah daun, pemberian pupuk organik cair rumput laut Sargassum sp. memberikan pengaruh nyata hanya pada pengamatan 10 HST, 20 HST, 30 HST, 40 HST dan 50 HST sedangkan pada pengamatan umur 63 HST, pemberian pupuk organik cair rumput laut Sargassum sp. tidak memberikan pengaruh yang nyata.

Dari semua perlakukan makan perlakuan P3 (konsentrasi 15m1/liter) terbaik karena memiliki rata-rata pertumbuhan tinggi tanaman, jumlah daun dan bobot panen tertinggi yang berbeda dengan perlakuan P0 (tanpa pemberian pupuk organik cair) memiliki rata-rata pertumbuhan tinggi tanaman, jumlah daun dan bobot panen terendah. 
KADEK LENI. et al. Peningkatan Produksi Tanaman Bawang Daun (Allium Fistusolum)...

\section{DAFTAR PUSTAKA}

Ambarita, R., et al. 2015. Penggunaan Rumput Laut Laut (Sargassum Polycystum) Sebagai Bahan Pupuk Cair Dan Pengaruhnya Terhadap Kandungan N, $\mathrm{P}, \mathrm{K}, \mathrm{Ca}, \mathrm{Mg}$ Tanah Ultisol Dan Produksi Sawi ( Brassica Juncea L. ) Organik Volume 2, Nomor 2 : 793 - 802. Fakultas Pertanian USU : Medan

Basmal, J., et al. 2009. Mekanisasi proses pengeringan dan sistem pemisahan filtrat rumput laut. Laporan Akhir Penelitian Mekanisasi Proses. Balai Besar Riset Pengolahan Produk dan Bioteknologi Kelautan dan Perikanan : Jakarta.

Berlyanto, B., et al. 2014. Pupuk Cair Dari Rumput Laut Eucheuma cottonii, Sargassum sp. dan Gracilaria sp. Menggunakan Proses Pengomposan Volume 9 Nomor 1: 6168. Penelitian dan Pengembangan Mekanisasi Pengolahan Hasil Perikanan: Yogyakarta.

Cahyono, B. 2005. Bawang Daun. Kanisius : Yogyakarta

Hisani, W., 2017. "Pemanfaatan Mulsa Organik Serta Aplikasi Pupuk organik cair Dari Limbah Rumput Laut (Gracilaria Sp.) Dan Urine Sapi Untuk Pertumbuhan Dan Produksi Kedelai Varietas Wilis (Glycine Max L.)". Jurnal Pertanian Berkelanjutan. Volume 6 Nomor 1 Halamanan 43-51 Fakultas Pertanian, Universitas

Cokroaminoto Palopo : Silawesi Selatan. Sapto W., 2015. "Penetapan Standar Warna Daun Sebagai Upaya Identifikasi Status Hara (N) Tanaman Jagung (Zea mays L.) pada Tanah Ragosol". Jurnal Agro Science. Volume 3 No 1. 